\title{
Segregation along multiple resource axes in a tropical seagrass fish community
}

\author{
Ivan Nagelkerken ${ }^{1,2, *}$, Gerard van der Velde ${ }^{1}$, Wilco C. E. P. Verberk ${ }^{1}$, \\ Martijn Dorenbosch ${ }^{1}$
}

\author{
${ }^{1}$ Department of Animal Ecology and Ecophysiology, Institute for Water and Wetland Research, \\ Radboud University Nijmegen, Toernooiveld 1, 6525 ED Nijmegen, The Netherlands \\ ${ }^{2}$ Carmabi Foundation, PO Box 2090, Piscaderabaai z/n, Curaçao, Netherlands Antilles
}

\begin{abstract}
Segregation of resources is supposed to be a mechanism for coexistence of species and/or life stages when resources are limiting and competition between species occurs. In seagrass beds, fish species richness is lower than on coral reefs, but food abundance is in general higher. In this case, food segregation may not occur. Here, the null hypothesis is tested that species show no segregation in feeding with respect to time, space and diet. The structure of the food web in a tropical seagrass bed revealed that the seagrass fish community consisted of species feeding at 3 trophic levels: (1) herbivores, (2) omnivores, zoobenthivores and zooplanktivores, and (3) piscivores. The data suggest that herbivores partitioned food by specialising on seagrass epiphytes, seagrass leaves or macroalgae from the seagrass bed, with 1 species presumably feeding in adjacent mangroves. Fishes at the second trophic level showed temporal segregation in feeding habits between fish families, while species within families showed segregation in food type and source. At the third trophic level, 1 piscivorous species was found. The majority of fish species showed a very narrow diet breadth with a significant segregation in resource-use. The null hypothesis was rejected since feeding segregation was not random for time, space and diet, viz. feeding time and diet (33.3\%), diet only $(25.5 \%)$, time, habitat and diet $(15.2 \%)$, habitat and diet $(13.4 \%)$, time only $(3.5 \%)$ and habitat only $(2.6 \%)$. Segregation in resource use was present along 1 to 3 resource axes simultaneously, which could support coexistence of species that favour comparable food types if food were limiting.
\end{abstract}

KEY WORDS: Resource segregation · Diet composition · Stable isotopes $\cdot$ Food web $\cdot$ Coastal habitats

\section{INTRODUCTION}

Species richness in animal communities of marine ecosystems is influenced by several factors. These include abiotic variables (e.g. habitat structure, temperature, salinity), species interactions (e.g. predation, competition), degree of stability, and exchange with adjacent habitats (Tilman 1994, Chesson 2000). Tropical seagrass beds are characterised by a high species richness compared to other, structurally less complex, habitat types. These ecosystems harbour resident species (i.e. species completing most or all of their life cycle there), nursery species (species using the ecosystems only during their juvenile stage) and occasional visitors (species visiting from adjacent ecosystems), all of which are able to coexist in a single ecosystem
(Blaber 2000). In the Caribbean, seagrass fish communities in bays and lagoons mostly consist of nursery species (Parrish 1989, Nagelkerken et al. 2000b). The species occurring in these seagrass beds must possess adaptations to survive in a habitat which has its own specific characteristics. Nagelkerken \& van der Velde (2004a) showed that fishes of seagrass beds had different ecological traits than those from adjacent sand/ mud bottoms. Such adaptations are particularly important for resident species.

Shallow-water habitats such as seagrass beds provide an extension of the available habitat space for coral reef fish species. The degree to which these species depend on such a habitat extension differs between species; those found in seagrass beds primarily use this habitat as a shelter and foraging area (Parrish 
1989). Seagrass beds provide a high degree of structural complexity, thus creating a higher diversity of niches (Orth et al. 1984). As a result they can harbour a relatively high biodiversity. Since many coastal ecosystems, including seagrass beds, can contain high animal densities and species numbers, the question arises as to how populations of different species manage to coexist in these ecosystems.

Coexistence of species occurs in a number of situations: (1) When advantages during one life-stage (e.g. lower mortality of adults) imply disadvantages during another life-stage (e.g. lower fecundity of juveniles) as a result of ontogenetic differences in life history strategies (McCann 1998); (2) when niches are undersaturated and, through factors such as disturbance, disease or predation, populations do not reach sufficiently high densities for strong interactions (Huston 1979); (3) when there is some degree of segregation in time, space, or food (Schoener 1974).

According to the competitive exclusion principle, coexisting species must differ in their trophic niches when the environment is constant and homogeneous. If this is the case, then one species is likely to be excluded by being outcompeted by another species sharing the same niche (Townsend 1995). Therefore, coexisting species must either utilise different resources, utilise the same resource but within a different microhabitat, or utilise the same resource at a different time. Communities structured in this way are defined as 'niche-controlled' (Yodzis 1986). Species diversity in seagrass beds may thus be partly explained by different ecological requirements of species in relation to the range in microhabitats and food types present, viz. by so called 'niche-control' (Townsend 1995). This only applies, however, if resources are limiting and competition occurs. If this is not the case, patterns of resource-use may overlap (Sale 1974). Experiments which vary the degree of resource availability are often not technically feasible, but studies on resource overlap are. Although the presence of resource segregation does not prove interspecific competition for food, it can assess whether competition may have played a role during the course of the coexistence of the fishes (Sale 1974).

The degree of resource segregation in fish communities of seagrass beds has received little attention. Furthermore, many detailed studies have been carried out on the diet composition of some fish species on seagrass beds (see reviews by Pollard 1984, Parrish 1989, Blaber 2000), but little is known so far about the trophic functioning of entire seagrass fish communities. Many studies have focussed on a narrow selection of fish species, and knowledge about resourcepartitioning between fish species is biased towards the subadult and adult stages (Ross 1986).
In the present study we investigated the degree of resource segregation in a complete seagrass fish community, by testing the null hypothesis that species show no segregation with respect to time, space and food. For this we used both gut-content analysis (providing information about food-partitioning) and stable carbon and nitrogen isotope analysis (providing information about where the food was obtained).

\section{MATERIALS AND METHODS}

Study area. The study was carried out in Spanish Water Bay on the Caribbean island of Curaçao, Netherlands Antilles. The bay has a maple-leaf shape, with a total surface area of approximately $3 \mathrm{~km}^{2}$, and is mostly less than $6 \mathrm{~m}$ deep (Fig. 1). The shoreline of the bay is fringed by Rhizophora mangle mangrove trees whose prop-roots are always inundated. Monospecific Thalassia testudinum seagrass beds are located in front of the mangroves at depths of 0.4 to $3 \mathrm{~m}$. Mean $( \pm \mathrm{SD})$ seagrass cover in the bay at the time of the study was $81 \pm 12 \%$, height of the seagrass canopy above the substratum was $22 \pm 8 \mathrm{~cm}$, and seagrass shoot density was $143 \pm 66 \mathrm{~m}^{-2}$. Based on shoot density, the seagrass bed can be considered as being rather thin, but the relatively long overhanging seagrass leaves provide a seagrass canopy of high cover and sufficient shelter for fishes. At depths between approximately 3 and $6 \mathrm{~m}$, the bay consists of a subtidal muddy/sandy seabed with a low algal cover $(<20 \%)$ comprising Halimeda opuntia, H. incrassata, Cladophora sp. and Caulerpa verticillata (Kuenen \& Debrot 1995). There is a deep channel (depth between 11 and $18 \mathrm{~m}$ ) in the central parts of the bay (Fig. 1).

Mean $( \pm \mathrm{SD})$ water temperature and salinity in the seagrass beds were $28.3 \pm 0.2^{\circ} \mathrm{C}$ and $35.4 \pm 0.2$, respectively. The bay has relatively clear water with an average horizontal Secchi disk visibility of $6.2 \pm 2.1 \mathrm{~m}$. The average daily tidal range is about $30 \mathrm{~cm}$ (de Haan \& Zaneveld 1959).

Sampling design. Multiple stable-isotope and gutcontent analyses were both used to improve the ability to detect food-partitioning among fishes of seagrass beds. The disadvantages of gut-content data are that they provide only snapshots of feeding habits, and that food items from guts may be unidentifiable, may be processed at different rates, or may be resistant to digestion and not assimilated at all, and could thus be over- or under-represented. Furthermore, since many fishes undertake diurnal or tidal feeding migrations between different habitats, it is often difficult to determine the origin of the food in a fish's stomach. Therefore, gut-content analysis was necessary to determine which food type had been consumed, and stable- 
isotope analysis was necessary to distinguish the trophic level and food source (i.e. type of habitat).

Fishes were collected between May and September 1998 from seagrass beds in Spanish Water Bay (Fig. 1), using a beach seine net. Collections were made in the morning (around 10:00 h) to ensure the presence of filled stomachs in nocturnally as well as diurnally active fish species; diet analysis confirmed that most guts contained food. Gut-content analysis followed the methods of Cocheret de la Morinière et al. (2003) and Nagelkerken \& van der Velde (2004b).

The muscle tissue of the 29 fish species caught on seagrass beds (see Table 1) and several potential food items from the seagrass beds were sampled for stable carbon and nitrogen analysis. Further details on the procedure can be found in Nagelkerken \& van der Velde $(2004 b, c)$. Stable-isotope ratios of animals reflect those of their diet, whereby a consumer shows an average $1 \%$ enrichment in carbon with its food source and an average 3\% enrichment in nitrogen (DeNiro \& Epstein 1978, Rau et al. 1983, Fry 1984, 1988, Minagawa \& Wada 1984), although vari- ations in $\delta^{15} \mathrm{~N}$ enrichment can sometimes be more substantial (DeNiro \& Epstein 1981, Minagawa \& Wada 1984).

Data analysis. For each combination of fish species, the Schoener's index of diet overlap $\left(O_{j k}\right.$, Schoener 1970) was calculated as:

$$
O_{j k}=1-0.5\left(\Sigma\left|p_{i j}-p_{i k}\right|\right)
$$

where $p_{i j}$ and $p_{i k}$ are the proportions of the $i$ th resource (prey item) consumed by Species $j$ and $k$, respectively. The index ranges from 0 (no overlap) to 1 (complete overlap), with values $>0.6$ representing a significant overlap (Scrimgeour \& Winterbourn 1987, Sala \& Ballesteros 1997).

Diet breadth was calculated for each species using Levin's standardised index (Hurlbert 1978):

$$
B_{i}=\frac{1}{n-1}\left(\frac{1}{\sum_{j} p_{i j}^{2}}-1\right)
$$

where $B_{i}=$ Levin's standardised index for Fish $i, n=$ the number of food categories, and $p_{i j}=$ the proportion of the diet of Fish $i$ that is made up of Food $j$. The index

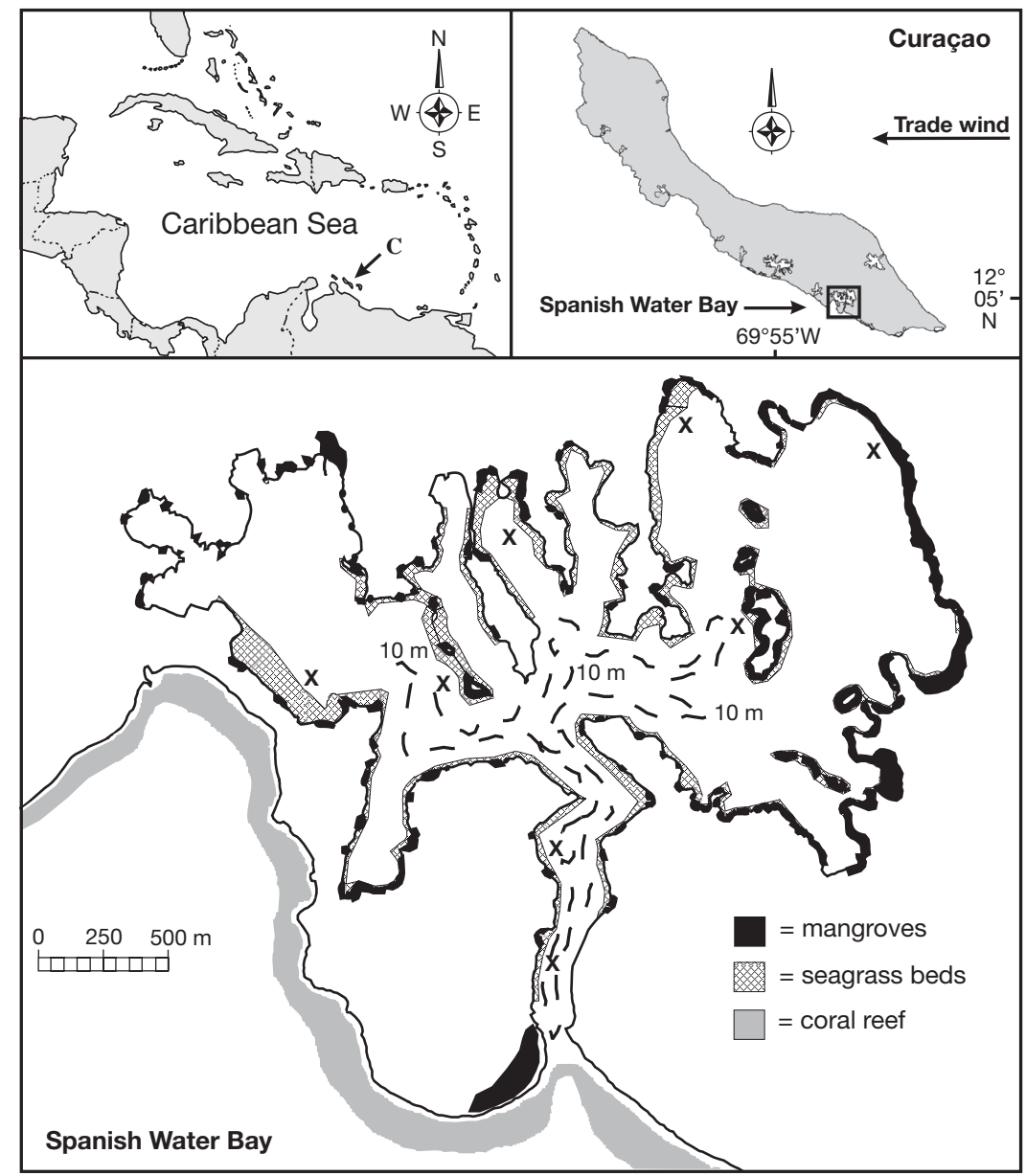

Fig. 1. Locations of Curaçao (C), Spanish Water Bay, and sites of fish collection $(\mathbf{X})$ in the seagrass beds 


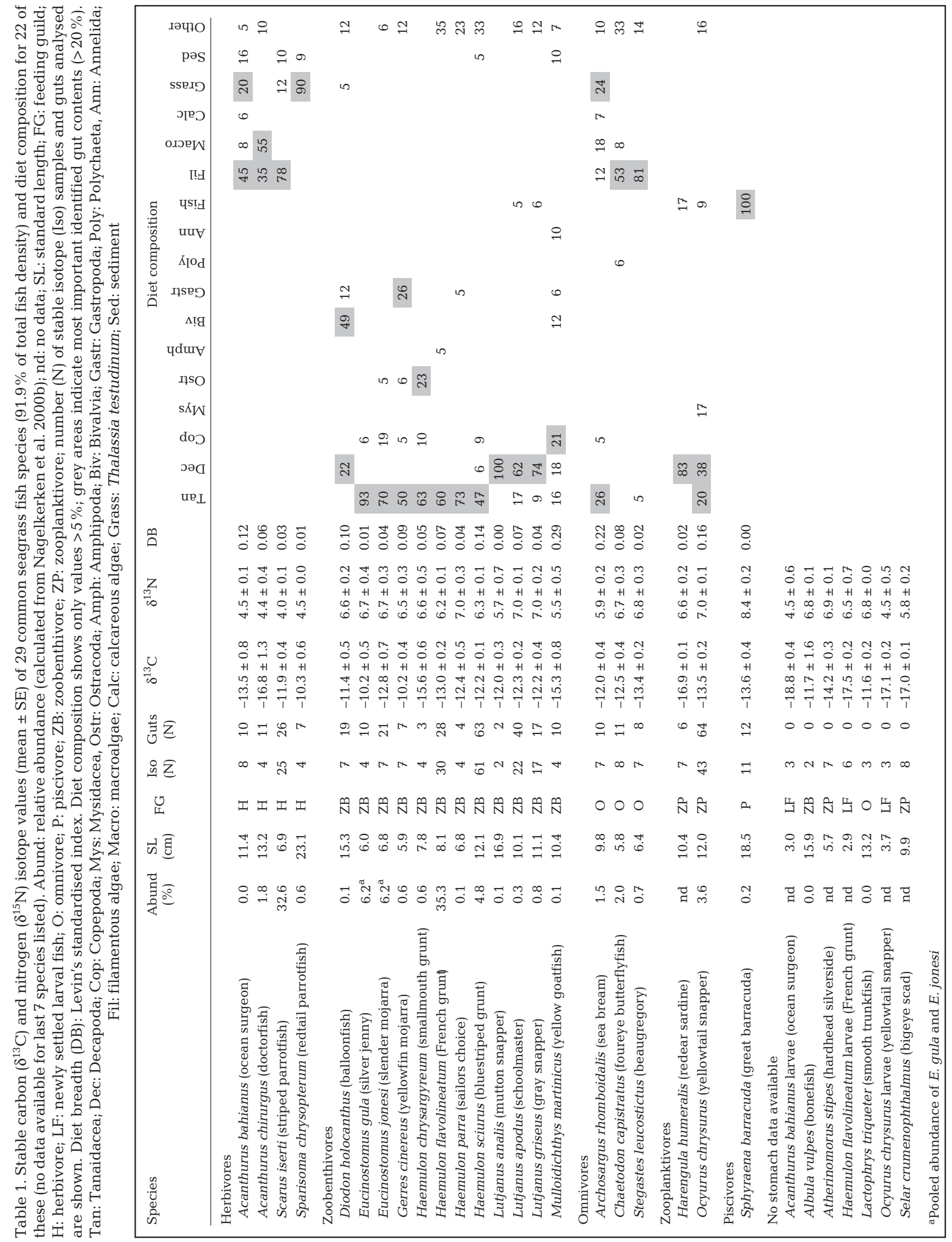


ranges from 0 to 1 , with low values indicating diets dominated by a few food items.

Statistical differences in $\delta^{13} \mathrm{C}$ and $\delta^{15} \mathrm{~N}$ were tested using Student's $t$-tests (2 variables) or 1-way ANOVAs ( $>2$ variables). ANOVAs were followed by a Hochberg's GT2 post-hoc test for comparison of means. For comparisons of the omnivores, the variances were not homogene (Levene's test) and a Games-Howell test was used instead (Field 2002).

\section{RESULTS}

\section{Trophic structure of fish and invertebrate community}

The 29 selected fish species represented $91.9 \%$ of the total fish density in the seagrass beds of Spanish Water Bay (Table 1). The 2 most dominant species were Scarus iserti and Haemulon flavolineatum, each accounting for about one-third of the total seagrass fish density. Less dominant species (1.5 to $6.2 \%$ of total density) were Acanthurus chirurgus, Eucinostomus spp., H. sciurus, Archosargus rhomboidalis, Chaetodon capistratus and Ocyurus chrysurus. The remaining species contributed $<0.8 \%$ to the total fish community.

Potential food items from the seagrass beds showed a clear difference in average $\delta^{15} \mathrm{~N}$ values (Fig. 2a), with values increasing from seagrass-related flora (seagrasses detritus, epiphytes, and leaves; mean = $0.3 \%$ ), through macroalgae $(2.4 \%$ ), to zooplankton and macrozoobenthos species $(4.4 \%$ ), excluding the 3 groups Ophiuroidea, Mysidacea and particulate organic matter, all of which had relatively high $\delta^{15} \mathrm{~N}$ values $(6.5 \%)$.

Based on differences in average $\delta^{15} \mathrm{~N}$ values, the seagrass fish community was segregated into 3 trophic levels (Fig. 2b): (1) primary consumers (herbivores; mean $\delta^{15} \mathrm{~N}=4.3 \%$ ), (2) secondary consumers (omnivores, zoobenthivores and zooplanktivores; mean $\delta^{15} \mathrm{~N}=6.5 \%$ ), and (3) tertiary consumers (piscivores; mean $\delta^{15} \mathrm{~N}=8.4 \%$ ). Both the primary (2 subclusters) and the secondary (3 subclusters) consumers were further subdivided into several subclusters with a similar average $\delta^{15} \mathrm{~N}$, but a different range in average $\delta^{13} \mathrm{C}$ values, indicating considerable difference in their carbon sources (Fig. 2b).

\section{Herbivores}

The 4 herbivores Acanthurus bahianus, A. chirurgus, Scarus iserti and Sparisoma chrysopterum showed clear differences in average $\delta^{13} \mathrm{C}$ values (Fig. 2b) and relatively low degrees of dietary overlap (Table 1), indicating segregation of their diet (Table 2). The stable-isotope data for $S$. iserti suggest that it feeds almost exclusively on seagrass epiphytes (based on an average $\delta^{13} \mathrm{C}$ enrichment of $1 \%$ and an average $\delta^{15} \mathrm{~N}$ enrichment of $3 \%$ between a consumer and its food), consisting mainly of filamentous algae (Fig. 2a). Gut-content analysis (Table 1) and observations in the field (I. Nagelkerken pers. obs.) have confirmed that juvenile $S$. iserti feed mainly on epiphytic filamentous algae.

For Sparisoma chrysopterum, the stable-isotope data suggest a diet of seagrass leaves with epiphytes (Fig. 2).
Fig. 2. Mean $\delta^{13} \mathrm{C}$ and $\delta^{15} \mathrm{~N}$ values of (a) potential food items and (b) fishes collected from seagrass beds in Spanish Water Bay. In (a) decapods are separated into crabs and shrimps; epiphytes on seagrass leaves consist largely of filamentous algae; POM: particulate organic matter in water column. In (b) fishes with similar stable-isotope values are encircled by numbered ellipses; H: herbivore; LF: newly settled larval fish; O: omnivore; P: piscivore; ZB: zoobenthivore; ZP: zooplanktivore. Full species names in Table 1, together with SEs for $\delta^{13} \mathrm{C}$ and $\delta^{15} \mathrm{~N}$ 


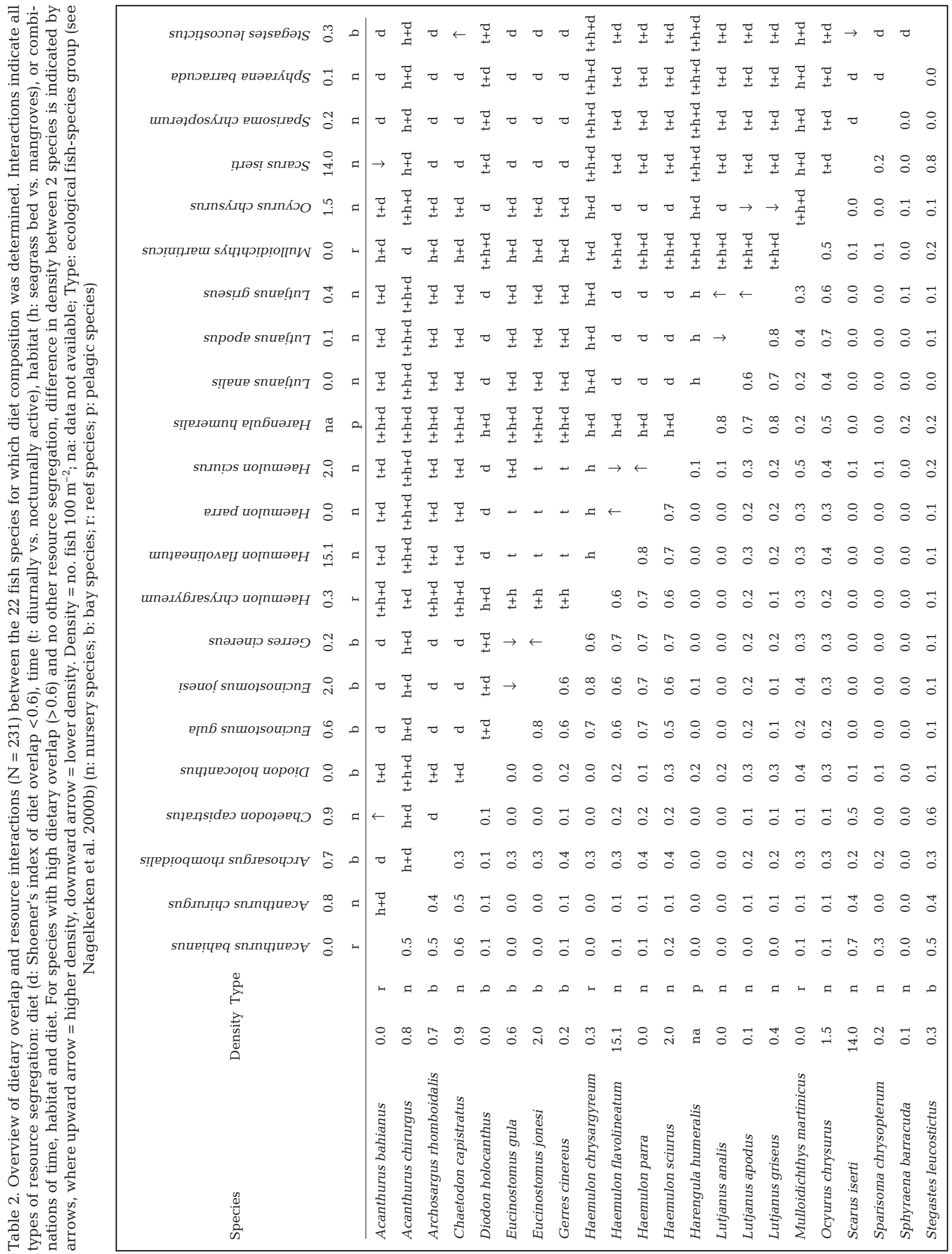


The gut-content analysis confirmed that seagrass leaves were the main source of food (90\%; Table 1$)$.

Acanthurus bahianus showed depleted $\delta^{13} \mathrm{C}$ values (average -13.5\%) compared to Scarus iserti and Sparisoma chrysopterum (average -10.3 and $-11.9 \%$, respectively). The contents of its digestive tract comprised mainly filamentous algae (45\%) and some seagrass $(20 \%)$ (Table 1$)$, but the $\delta^{13} \mathrm{C}$ values of its tissue showed that it was depleted, rather than enriched, relative to these 2 food items (Fig. 2b). This indicates that its diet also included a more depleted food source, in this case probably macroalgae $(8 \%$ of the digestive tract content).

The mean $\delta^{13} \mathrm{C}$ value of Acanthurus chirurgus $(-16.8 \%$ o ) was significantly depleted $(\mathrm{p}<0.050$, Hochberg's GT2 test) compared to that of the other 3 herbivores. Gut-content analysis showed that macroalgae were the main food source (55\%; Table 1$)$. Taking an average $\delta^{13} \mathrm{C}$ value of $-20.1 \%$ for mangrove macroalgae (Nagelkerken \& van der Velde 2004b) and an average $-15.0 \%$ o for seagrass macroalgae (Fig. 2a) into account, the data suggest a mixed diet of macroalgae from the mangroves and seagrass beds and spatial separation of feeding habitat from that of the other herbivore species (Table 2).

\section{Zoobenthivores and omnivores}

Most zoobenthivores and omnivores had $\delta^{13} \mathrm{C}$ values that were in accordance with macroinvertebrates from the seagrass bed as food source (Fig. 2). Most species showed an extremely narrow dietary breadth (Table 1) indicating the presence of a large number of specialist feeders on the seagrass bed. However, a high number of species fed on Decapoda or Tanaidacea (Table 1). Nevertheless, a more in-depth analysis of the data suggests a significant degree of resource-partitioning along different resource axes (see below and Table 2).

Gerreidae and Haemulidae foraged predominantly on Tanaidacea, whereas Lutjanidae foraged mainly on Decapoda (Table 1). Gerreidae (diurnal feeders) and Haemulidae (nocturnal feeders) did not compete for food as they were temporally segregated when feeding (Table 2). Among the Gerreidae, the $\delta^{13} \mathrm{C}$ values of Eucinostomus gula and E. jonesi differed significantly ( $p=0.035$, Student's $t$-test) in $\delta^{13} \mathrm{C}$ by, on average, $2.6 \%$ (Fig. 2b). They both fed predominantly on Tanaidacea (Table 1), but $24 \%$ of E. jonesi's diet also consisted of zooplankton (Copepoda and Mysidacea), which probably explains its lower $\delta^{13} \mathrm{C}$ value compared to E. gula. E. gula and Gerres cinereus had the same $\delta^{13} \mathrm{C}$ signature, but the latter had a broader diet, including a significant contribution by Gastropoda (26\%). Among the Haemulidae, Haemulon chrysargyreum had a highly depleted average $\delta^{13} \mathrm{C}$ value (Fig. 2b). The other 3 Haemulon species had more comparable values, but a significant difference in $\delta^{13} \mathrm{C}(\mathrm{p}=0.021$, Hochberg's GT2 test) was found between $H$. flavolineatum and $H$. sciurus. This was supported by the gut-content analysis, which revealed some difference in composition of the diet between these 2 species (Table 1). Among the Lutjanidae, the nocturnally active Lutjanus apodus and L. griseus had almost the same gut contents and $\delta^{13} \mathrm{C}$ and $\delta^{15} \mathrm{~N}$ values, which could indicate competition for food sources. The $\delta^{15} \mathrm{~N}$ value of $L$. analis was on average $1.3 \%$ lower ( $p<0.019$, Hochberg's GT2 test) than that of the other 2 species, suggesting a different food source for this species. This was confirmed by the diet analysis, which revealed a gut content comprising $100 \%$ Decapoda for L. analis, and a mixture of Tanaidacea and Decapoda for the other 2 species.

Diodon holocanthus had an average $\delta^{13} \mathrm{C}$ value that differed clearly from that of the other zoobenthivores (except Albula vulpes), and foraged predominantly on bivalves (49\% gut content) and decapods (22\%) (Table 1, Fig. 2). Since it was the only species specialising on bivalves, it probably did not compete significantly for food with other zoobenthivores in the seagrass bed (Table 2).

Compared to the other zoobenthivores, Haemulon chrysargyreum and Mulloidichthys martinicus had highly depleted $\delta^{13} \mathrm{C}$ values (average $-15.5 \%$ ). These values were in accordance with food from the mangroves $(-16$ to $-21 \%$; Nagelkerken \& van der Velde 2004b), suggesting spatial separation in food habitat from the other zoobenthivores (Table 2).

The gut contents of the omnivores Chaetodon capistratus and Stegastes leucostictus consisted mainly of filamentous algae (Table 1), and their $\delta^{13} \mathrm{C}$ values did not differ significantly ( $p=0.234$, Games-Howell test). However, there was a significant difference $(p<0.050$, Games-Howell test) in $\delta^{13} \mathrm{C}$ values between $S$. leucostictus and both Archosargus rhomboidalis and LaCtophrys triqueter (Fig. 2b). C. capistratus and S. leucostictus also forage on animal food (Randall 1967), as was clear from their high $\delta^{15} \mathrm{~N}$ values, which lay within the range of those for carnivores rather than those for herbivores (Fig. 2b); this is probably also true for the omnivore $L$. triqueter, which had similar $\delta^{15} \mathrm{~N}$ values. The omnivore $A$. rhomboidalis had a significantly lower average $\delta^{15} \mathrm{~N}$ than $L$. triqueter, and its high dietary breadth indicated that it is a more generalist feeder than the other omnivores (Table 1).

\section{Zooplanktivores and larval fishes}

The 4 zooplanktivore species could be divided into 2 groups with very different $\delta^{13} \mathrm{C}$ signatures (Fig. 2b). 
The first group comprised Harengula humeralis and Selar crumenophthalmus, whose $\delta^{13} \mathrm{C}$ values were very low compared to those of other fishes from the seagrass bed, but similar to those of newly settled larvae of Acanthurus bahianus, Haemulon flavolineatum and Ocyurus chrysurus, with an oceanic stable-carbon signature (average -19 to $-17 \%$ ). For Harengula humeralis or S. crumenophthalmus the stable-isotope data indicate a diet consisting of zooplankton (Fig. 2). The second group consisted of Atherinomorus stipes and Ocyurus chrysurus, with $\delta^{13} \mathrm{C}$ values within the range of values for fishes feeding in the seagrass bed (Fig. 2b). The diet of $O$. chrysurus consisted of both benthic Tanaidacea and Decapoda, and of pelagic Mysidacea (Table 1). Likewise, the stable-isotope data support a mixed diet of zooplankton and benthic crustaceans (Fig. 2). For $A$. stipes no diet data were available, but the stable-isotope data do not indicate selective feeding on zooplankton only, since the $\delta^{13} \mathrm{C}$ values of zooplankton was too low compared with that of this fish species.

\section{Piscivores}

The only obligatory piscivore inhabiting the seagrass beds, Sphyraena barracuda, had the highest average $\delta^{15} \mathrm{~N}$ value of all fishes, as would be expected for a top predator. However, its average $\delta^{13} \mathrm{C}$ value was depleted relative to all but 1 seagrass fish species (Atherinomorus stipes; Fig. 2a). Considering an average of $1 \%$ enrichment between prey and predator, the stable-isotope data indicate that its diet could consist of the pelagic silverside A. stipes or of a mixture of the carbon-depleted pelagic Harengula humeralis and Selar crumenophthalmus and carbon-enriched benthic seagrass fish species.

\section{Differences in resource utilisation}

On the basis of differences in feeding time, feeding habitat and diet, a conceptual model of the food-web structure of the fish community of the seagrass bed was constructed (Fig. 3). Species were segregated along 1 to 3 different resource axes simultaneously (Table 2): feeding time and diet $(33.3 \%)$, diet only $(25.5 \%)$, time, habitat and diet (15.2\%), habitat and diet $(13.4 \%)$, time only $(3.5 \%)$, habitat only $(2.6 \%)$. Absence of segregation was found for only $6.5 \%$ of the species.

\section{DISCUSSION}

Seagrass was consumed by several herbivorous species. Although many animals ingest seagrass leaves (Randall 1967, McRoy \& Helfferich 1980), it is generally considered to be of little nutritional importance (Fry 1984, Kitting et al. 1984, Moncreiff \& Sullivan 2001). One Caribbean reef fish is known to live almost exclusively on seagrass leaves, viz. the bucktooth parrotfish Sparisoma radians (Randall 1967, Lobel \& Ogden 1981). The present study has shown that Sparisoma chrysopterum also feeds almost exclusively on seagrass leaves, and the stable isotope data confirmed that this food is also assimilated. Scarus iserti and Sparisoma chrysopterum fed on closely associated food types, but whereas the former fed only on seagrass epiphytes, the latter consumed the entire seagrass leaves, including epiphytes. However, these species appear to be spatially separated in the seagrass beds. Scarus iserti was mainly observed to feed on epiphytes while swimming in schools above the seagrass canopy, whereas juvenile Sparisoma chrysopterum were always observed roaming under the seagrass canopy between the shoots (I. Nagelkerken pers. obs.). Although the seagrass blades consumed by $S$. chrysopterum bear the epiphytes that are consumed by Scarus iserti, the 2 species probably do not compete for food, as both food sources are highly abundant in the seagrass beds and thus probably non-limiting.

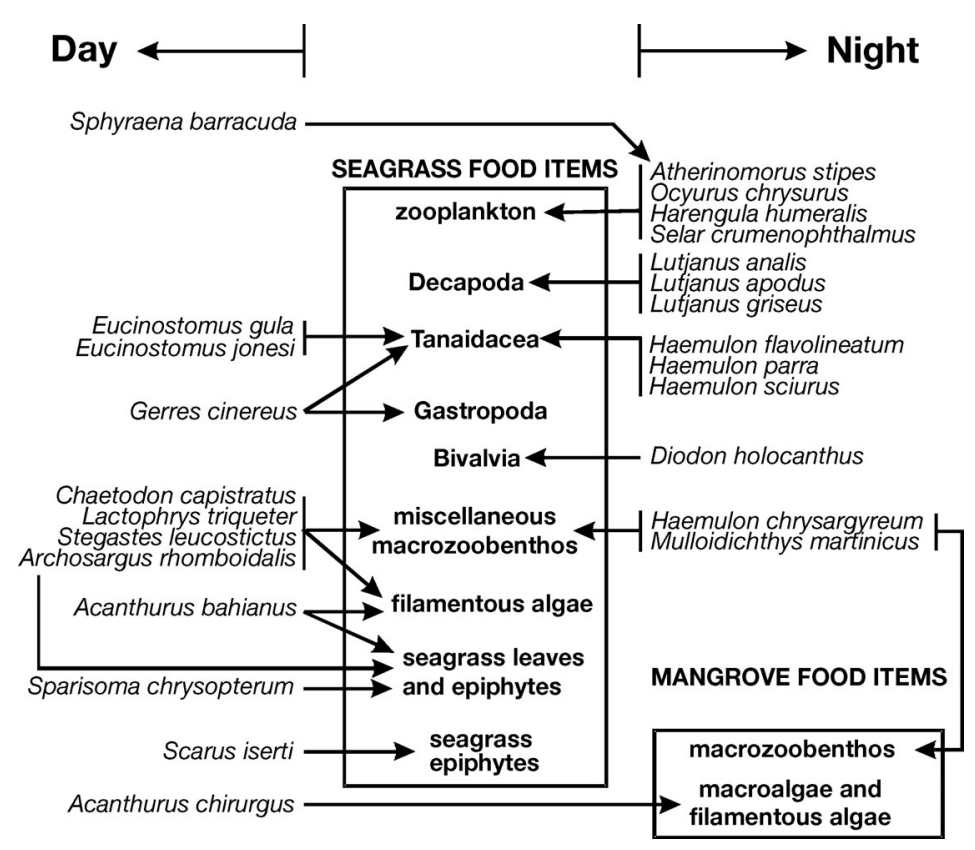

Fig. 3. Conceptual model of food web structure of fish community of seagrass beds in Spanish Water Bay. Day/night activity patterns from Starck \& Davis (1966) and Collette \& Talbot (1972) 
The zoobenthivores displayed several differences in diet and stable-isotope values, suggesting some degree of segregation in food. They may further avoid interspecific food competition by spatial separation during feeding. Ogden \& Zieman (1977) showed that Haemulon flavolineatum and $H$. plumieri (both of which occurred in high densities in the seagrass beds at St. Croix) may avoid competition by homogenous distribution in favoured feeding areas along fixed migration routes, and by differential preference for either dense seagrass beds or more open sandy seagrass beds. Burke (1995) found a similar result for $H$. flavolineatum and $H$. sciurus.

The larval fishes had $\delta^{13} \mathrm{C}$ signatures (-19 to $-17 \%$ ) close to those of mangrove invertebrates (-25 to -19\%; Rodelli et al. 1984, Stoner \& Zimmerman 1988, Marguillier et al. 1997, Lee 2000, Schwamborn et al. 2002), but these are an unlikely food source. Since stable isotopes from food sources accumulate in muscle tissue in terms of weeks to months (Gearing 1991), or during a 4-fold increase in weight for fast-growing organisms (Fry \& Arnold 1982), it is more likely that these recently settled fishes still possessed an offshore carbon signature typical of pelagic species and their planktonic food; stable carbon-isotope values of phyto-/zooplankton and of pelagic fishes from the open ocean typically lie around -22 to $-20 \%$ and -18 to $-16 \%$, respectively (Fry et al. 1982, Rau et al. 1983, Rodelli et al. 1984, Boutton 1991, Herzka et al. 2001). The 2 zooplanktivores Harengula humeralis and Selar crumenophthalmus are pelagic species that seasonally enter the bays of Curaçao (Zaneveld 1962). Although their stableisotope signatures support a diet based on seagrass zooplankton, it cannot be determined to what degree they also feed on oceanic zooplankton.

The stable-isotope data indicate that the only piscivore, Sphyraena barracuda, appears to feed on the pelagic Atherinomorus stipes. Our field observations showed that large schools of A. stipes (and small anchovies and herrings) shelter at the mangroveseagrass interface during the daytime, which coincides with the location where $S$. barracuda is often observed. Furthermore, the gut-content analysis revealed predominantly silversides, anchovies and herrings in the diet of $S$. barracuda. It cannot be excluded, however, that the diet of $S$. barracuda is based on a mixture of benthic fish species that forage exclusively in the seagrass beds (i.e. $\delta^{13} \mathrm{C}>-14 \%$ ) and pelagic species such as Harengula humeralis and Selar crumenophthalmus with a depleted $\delta^{13} \mathrm{C}$ signature (average of $-17 \%$ ).

Segregation in feeding time was especially obvious for fishes feeding on macrozoobenthos. Segregation in terms of food occurred between and within fish families and feeding guilds, with most species specialising on specific food items and only a few consuming a wide variety of food items. Some species showed spatial segregation in feeding habitats by apparently foraging in adjacent mangroves. Food specialisation and segregation is a possible explanation for a diverse fish community with a high number of coexisting fish species within a seagrass bed.

When food abundance is limiting and species compete for food, overlap of resource use is usually small (Sale 1974). In Spanish Water Bay, however, the abundance of the food types most commonly eaten by the seagrass fish community (seagrass leaves, seagrass epiphytes, Tanaidacea, macrozoobenthos) is much higher in the seagrass beds than in other bay habitats and on the coral reef (Nagelkerken et al. 2000a, 2001). Even though resources are possibly not limiting in the seagrass beds, the fish community of the seagrass bed displayed a very narrow dietary breadth, and a significant degree $(93.5 \%)$ of resource partitioning by fish species. The previously formulated null hypothesis can therefore be rejected, since fishes showed a nonrandom segregation along several resource axes. The question remains as to why such a high degree of resource-partitioning was observed. Although such partitioning does not prove the existence of interspecific competition for food, it can indicate that competition may have played a role in the evolution of the coexistence of the fishes (Sale 1974). The seagrass beds have a lower species richness than the adjacent coral reefs, but a much higher density of juvenile fish species of specific genera that probably use this habitat as a nursery (Nagelkerken \& van der Velde 2002). These high fish densities of species favouring similar food types (e.g. algae or crustaceans) may have played a role in the high degree of niche segregation in the seagrass habitat.

Interestingly, species were not only segregated along 1 resource axis at a time $(31.6 \%)$, but also along $2(46.7 \%)$ or $3(15.2 \%)$ different resource axes. This type of multiscale segregation has not received much attention in studies on fish communities of tropical seagrass beds. If resources were limited and many species co-existed that fed on a limited set of food types, segregation along 1 resource axis might not be sufficient to avoid potential food competition. Segregation along multiple resource axes would in this case favour the coexistence of species with comparable feeding habitats, for example Gerreidae, Haemulidae, and Lutjanidae, which all feed on crustaceans.

Nowadays, most coastal ecosystems have been affected by historical human interference, such as overfishing, that has resulted in changes in their structure and functioning (Jackson et al. 2001). Also, Spanish Water Bay is surrounded by coastal development, of which the influence on the trophic structure of the seagrass bed fish community is unknown. 
In conclusion, the present study has shown that several seagrass fish species have a very narrow diet breadth, and that significant segregation in resourceuse is present. Segregation occurs along 1, 2 or sometimes 3 different resource axes at the same time: feeding time and diet $(33.3 \%)$, diet only $(25.5 \%)$, time, habitat and diet (15.2\%), habitat and diet $(13.4 \%)$, time only $(3.5 \%)$, and habitat only $(2.6 \%)$. In only $6.5 \%$ of the cases did species show no segregation in the resources studied. If resources are limited, coexistence of species in a diverse seagrass fish assemblage may arise though multi-axis resource-segregation. Independent of resource availability, the study has shown that even though fish species richness is much lower than on a coral reef, a relatively high degree of feeding specialisation does occur within the fish community of seagrass beds.

Acknowledgements. The samples from Curaçao were collected during several field studies supported by funds granted to I.N. by World Wildlife Fund, The Netherlands, the Prins Bernhard Fonds Nederlandse Antillen en Aruba, and the Schure-Beijerinck-Popping Fonds, and to M.D. and W.C.E.P.V. by the Schure-Beijerinck-Popping Fonds and the Stichting Nijmeegs Universitair Fonds (SNUF). We thank S. Kleijnen, T. Klop and R. A. C. J. van den Brand for their assistance in grinding the fish samples for stable isotope analysis, and J. Eygensteyn for analysing the stable isotopes. We thank Dr. B. Winkel for allowing us to use his pier and shed at the Spanish Water Bay, the management and personnel of the Carmabi Foundation for logistic support, and Dr. P. F. Sale for useful suggestions. This is Centre for Wetland Ecology publication No. 329.

\section{LITERATURE CITED}

Blaber SJM (2000) Tropical estuarine fishes. Ecology, exploitation and conservation. Fish Aquat Resour Ser 7. Blackwell Science, Oxford

Boutton TW (1991) Stable carbon isotope ratios of natural materials. II. Atmospheric, terrestrial, marine, and freshwater environments. In: Coleman DC, Fry B (eds) Carbon isotope techniques. Academic Press, San Diego, CA, p 173-185

Burke NC (1995) Nocturnal foraging habitats of french and bluestriped grunts, Haemulon flavolineatum and H. sciurus, at Tobacco Caye, Belize. Environ Biol Fish 42:365-374

Chesson P (2000) Mechanisms of maintenance of species diversity. Annu Rev Ecol Syst 31:343-366

Cocheret de la Morinière E, Pollux BJA, Nagelkerken I, van der Velde G (2003) Diet shifts of Caribbean grunts (Haemulidae) and snappers (Lutjanidae) and the relation with nursery-to-coral reef migrations. Estuar Coast Shelf Sci 57:1079-1089

Collette BB, Talbot FH (1972) Activity patterns of coral reef fishes with emphasis on nocturnal-diurnal changeover. Sci Bull Nat His Mus Los Angel Cty 14:98-124

de Haan D, Zaneveld JS (1959) Some notes on tides in Annabaai harbour, Curaçao, Netherlands Antilles. Bull Mar Sci Gulf Caribb 9:224-236

DeNiro MJ, Epstein S (1978) Influence of diet on the distribu- tion of carbon isotopes in animals. Geochim Cosmochim Acta 42:495-506

DeNiro MJ, Epstein S (1981) Influence of diet on the distribution of nitrogen isotopes in animals. Geochim Cosmochim Acta 45:341-351

Field A (2002) Discovering statistics using SPPP for Windows. Sage Publications, London

Fry $\mathrm{B}(1984){ }^{13} \mathrm{C} /{ }^{12} \mathrm{C}$ ratios and the trophic importance of algae in Florida Syringodium filiforme seagrass meadows. Mar Biol 79:11-19

Fry B (1988) Food web structure on Georges Bank from stable $\mathrm{C}, \mathrm{N}$, and S isotopic compositions. Limnol Oceanogr 33: $1182-1190$

Fry B, Arnold C (1982) Rapid ${ }^{13} \mathrm{C} /{ }^{12} \mathrm{C}$ turnover during growth of brown shrimp (Penaeus aztecus). Oecologia 54:200-204

Fry B, Lutes R, Northam M, Parker PL (1982) A ${ }^{13} \mathrm{C} /{ }^{12} \mathrm{C}$ comparison of food webs in Caribbean seagrass meadows and coral reefs. Aquat Bot 14:389-398

Gearing JN (1991) The study of diet and trophic relationships through natural abundance ${ }^{13} \mathrm{C}$. In: Coleman DC, Fry B (eds) Carbon isotope techniques. Academic Press, San Diego, CA, p 201-218

Herzka SZ, Holt SA, Holt GJ (2001) Documenting the settlement history of individual fish larvae using stable isotope ratios: model development and validation. J Exp Mar Biol Ecol 265:49-74

Hurlbert SH (1978) The measurement of niche overlap and some relatives. Ecology 59:67-77

Huston MA (1979) A general hypothesis of species diversity. Am Nat 113:81-101

Jackson JBC, Kirby MX, Berger WH, Bjorndal KA and 15 others (2001) Historical overfishing and the recent collapse of coastal ecosystems. Science 293:629-637

Kitting CL, Fry B, Morgan MD (1984) Detection of inconspicuous epiphytic algae supporting food webs in seagrass meadows. Oecologia 62:145-149

Kuenen MMCE, Debrot AO (1995) A quantitative study of the seagrass and algal meadows of the Spaanse Water, Curaçao, The Netherlands Antilles. Aquat Bot 51:291-310

Lee SY (2000) Carbon dynamics of Deep Bay, eastern Pearl River estuary, China. II. Trophic relationship based on carbon- and nitrogen-stable isotopes. Mar Ecol Prog Ser 205:1-10

Lobel PS, Ogden JC (1981) Foraging by the herbivorous parrotfish Sparisoma radians. Mar Biol 64:173-183

Marguillier S, van der Velde G, Dehairs F, Hemminga MA, Rajagopal S (1997) Trophic relationships in an interlinked mangrove-seagrass ecosystem as traced by $\delta^{13} \mathrm{C}$ and $\delta^{15} \mathrm{~N}$. Mar Ecol Prog Ser 151:115-121

McCann K (1998) Density-dependent coexistence in fish communities. Ecology 79:2957-2967

McRoy CP, Helfferich C (1980) Applied aspects of seagrasses. In: Phillips RC, McRoy CP (eds) Handbook of seagrass biology. An ecosystem perspective. Garland STPM Press, New York, p 297-343

Minagawa M, Wada E (1984) Stepwise enrichment of ${ }^{15} \mathrm{~N}$ along food chains: further evidence and the relation between $\delta^{15} \mathrm{~N}$ and animal age. Geochim Cosmochim Acta 48:1135-1140

Moncreiff CA, Sullivan MJ (2001) Trophic importance of epiphytic algae in subtropical seagrass beds: evidence from multiple stable isotope analyses. Mar Ecol Prog Ser 215: 93-106

Nagelkerken I, van der Velde G (2002) Do non-estuarine mangroves harbour higher densities of juvenile fish than adjacent shallow-water and coral reef habitats in Curaçao (Netherlands Antilles)? Mar Ecol Prog Ser 245:191-204 Nagelkerken I, van der Velde G (2004a) A comparison of fish 
communities of subtidal seagrass beds and sandy seabeds in 13 marine embayments of a Caribbean island, based on species, families, size distribution and functional groups. J Sea Res 52:127-147

Nagelkerken I, van der Velde G (2004b) Are Caribbean mangroves important feeding grounds for juvenile reef fish from adjacent seagrass beds? Mar Ecol Prog Ser 274: 143-151

Nagelkerken I, van der Velde G (2004c) Relative importance of interlinked mangroves and seagrass beds as feeding habitats for juvenile reef fish on a Caribbean island. Mar Ecol Prog Ser 274:153-159

Nagelkerken I, Dorenbosch M, Verberk WCEP, Cocheret de la Morinière E, van der Velde G (2000a) Day-night shifts of fishes between shallow-water biotopes of a Caribbean bay, with emphasis on the nocturnal feeding of Haemulidae and Lutjanidae. Mar Ecol Prog Ser 194:55-64

Nagelkerken I, Dorenbosch M, Verberk WCEP, Cocheret de la Morinière E, van der Velde G (2000b) Importance of shallow-water biotopes of a Caribbean bay for juvenile coral reef fishes: patterns in biotope association, community structure and spatial distribution. Mar Ecol Prog Ser 202:175-192

Nagelkerken I, van der Velde G, Cocheret de la Morinière E (2001) Fish feeding guilds along a gradient of bay biotopes and coral reef depth zones. Aquat Ecol 35:73-86

Ogden JC, Zieman JC (1977) Ecological aspects of coral reefseagrass bed contacts in the Caribbean. Proc 3rd Int Coral Reef Symp 1:377-382

Orth RJ, Heck KL, van Montfrans J (1984) Faunal communities in seagrass beds: a review of the influence of plant structure and prey characteristics on predator-prey relationships. Estuaries 7:339-350

Parrish JD (1989) Fish communities of interacting shallowwater habitats in tropical oceanic regions. Mar Ecol Prog Ser 58:143-160

Pollard DA (1984) A review of ecological studies on seagrassfish communities, with particular reference to recent studies in Australia. Aquat Bot 18:3-42

Randall JE (1967) Food habits of reef fishes in the West Indies. Stud Trop Oceanogr 5:665-847

Editorial responsibility: Otto Kinne (Editor-in-Chief), Oldendorf/Luhe, Germany
Rau GH, Mearns AJ, Young DR, Olson RJ, Schafer HA, Kaplan IR (1983) Animal ${ }^{13} \mathrm{C} /{ }^{12} \mathrm{C}$ correlates with trophic level in pelagic food webs. Ecology 64:1314-1318

Rodelli MR, Gearing JN, Gearing PJ, Marshall N, Sasekumar A (1984) Stable isotope ratio as a tracer of mangrove carbon in Malaysian ecosystems. Oecologia 61:326-333

Ross ST (1986) Resource partitioning in fish assemblages: a review of field studies. Copeia 1986:352-388

Sala E, Ballesteros E (1997) Partitioning of space and food by three fish of the genus Diplodus (Sparidae) in a Mediterranean rocky infralittoral ecosystem. Mar Ecol Prog Ser 152:273-283

Sale PF (1974) Overlap in resource-use, and interspecific competition. Oecologia 17:245-256

Schoener TW (1970) Nonsynchronous spatial overlap of lizards in patchy habitats. Ecology 51:408-418

Schoener TW (1974) Resource partitioning in ecological communities. Science 185:27-39

Schwamborn R, Ekau W, Voss M, Saint-Paul U (2002) How important are mangroves as a carbon source for decapod crustacean larvae in a tropical estuary? Mar Ecol Prog Ser 229:195-205

Scrimgeour GJ, Winterbourn MJ (1987) Diet, food resource partitioning and feeding periodicity of two riffle-dwelling fish species in a New Zealand river. J Fish Biol 31:309-324

Starck WA, Davis WP (1966) Night habits of fishes of Alligator reef, Florida. Ichthyol Aquar J 38:313-356

Stoner AW, Zimmerman RJ (1988) Food pathways associated with penaeid shrimps in a mangrove-fringed estuary. Fish Bull (Wash DC) 86:543-551

Tilman D (1994) Competition and biodiversity in spatially structured habitats. Ecology 75:2-16

Townsend CR (1995) Community organization in marine and freshwater environments. In: Barnes RSK, Mann KH (eds) Fundamentals of aquatic ecology, 2nd edn. Blackwell Science, Oxford, p 125-143

Yodzis P (1986) Competition, mortality and community structure. In: Diamond JM, Case TJ (eds) Community ecology. Harper \& Row, New York, p 480-491

Zaneveld JS (1962) The fishery resources of the Netherlands Antilles. Proc Gulf Caribb Fish Inst 14:137-171

Submitted: October 18, 2004; Accepted: August 16, 2005

Proofs received from author(s): January 23, 2006 